\title{
Determinants of Banks Profitability
}

\author{
Haroon Jabbar
}

\begin{abstract}
The study is conducted by taking 31 commercial banks operating in Pakistan for the period 20092012. The results revealed that banks profitability is significantly impacted by CAP and size while loan loss provision, deposit growth are form to have negative significant coefficients our results are robust as we imply panel data estimation techniques of fixed, common, and random effect model. Our results are in line with in past research done on the impact of internal factors on banks profitability.
\end{abstract}

\section{Introduction:}

The financial markets of South Asia are in transition due to deregulation and liberalization measures. These measures have facilitated and stimulated greater competition, improved the operational transparency, and has streamlined regulatory policies and achieved greater efficiency levels. Recently, the service sectors have shown a considerable presence in business world. The banking sector has been continuously subject to dramatic changes since many years. It is due to deregulation, technological improvement, and financial modernization as mentioned above. These factors surge in the form of management revenues and costs.

The management of banks is more concerned to generate an acceptable return keeping focus on risk exposures as well. The new focus on banking sector using online banking along with the conventional banking is also contributing to growth. ${ }^{1}$ The banking sector is considered as the backbone of any economy as it boosts the economic activities. In country like Pakistan, the banking sector contributes to major supplier of funds, and the stability of banking sector is major cause of concern in the economy. But the economy of Pakistan is continuously discouraging the performance of banks.

Therefore, it is becoming necessary to focus on determinants on banking sector profitability in Pakistan. The privatizations of public sector banks and mergers or consolidations have changed the ownership structure of banks. Such changes are getting further consideration either on international or national level. The sound financial system plays a great role in improvement of economic structure and infrastructure. The profitability determinants in banking system have been explored and observed, but we have found no consensus over them. A few studies considered only the characteristics of banks itself as determinants of profitability while other studies have considered the macroeconomic factors.

The scholars like Staikouras and Wood, 2004; Athanasoglou et al, 2008; Brissimis et al., 2008) have examined the bank-specific (capital ratio, operational efficiency, bank size), industry-specific (ownership and concentration) and macroeconomic (inflation, cyclic output) determinants on bank performance.

\section{Literature Review:}

Literature has provided many evidences which identify the major determinants of banks profitability. Some studies are conducted on a particular country and others on countries' panel but in this study we have only focused on the bank specific variables as major determinants of banks' profitability in Pakistan. The factors being focused are bank related and also reflect the management performance. These factors are greatly linked to management decisions and help to reflect the quality of management in brief. An eminence management leads to a superior performance of bank, therefore it is tricky to evaluate performance of banks directly. We have studied several types of financial statements. The balance sheet which ensures the financial position of specific bank, firm or company provides significant information about the allocation of resources with respect to management policies. The balance sheet items are worthy indicators of potential and capability of bank in accordance with stability and earnings in the market. The balance sheet can provide variety of variables which influence the bank's performance. The variables that have received more consideration in the literature are the deposits, assets, liabilities, capital ratio, credit risk, size and productivity.

The capital adequacy ratio influences positively on performance of banks. Demirguc-kunt and Huizinga found a positive relationship between banks profitability and capital ratio. They conducted a comprehensive study for both the developing and developed countries. They found that the larger banks are more efficient in managing their costs in order to increase their profit. $(7,8)$ The negative relationship between the profitability and expenses has been supported by Bourke and Jiang et al. The dependent variable is ROA which can be derived by dividing net income on its total assets. It reflects how efficiently the bank's real investment resources are used by bank's management in order to produce profits. $(7,9)$ The banks which have 
healthy capitalization have very little bankruptcy costs and produce relatively higher interest margins. (10) Naceur also conducted a study to find out the relationship between profitability and interest margin. 11 Such positive relationship between expenses and profitability has been observed in Tunisia by Naceur and by Guru et al. in Malaysia. 12 They found out that the profitability and interest margin are highly associated with capital ratio and large overheads. They found out that there is negative relationship between banks' profitability and higher loan ratios as documented by Hassan and Bashir, Staikouras and Wood. 1314 In another study, Goddard et al. found that bank's capacity to generate more revenue in European countries is increased due to growth of banks.

Athanasoglou et al. conducted a study to analyze the relationship between the bank specific, industry specific, macroeconomic specific and profitability of Greek banks. They stated a positive significant relationship between banks profitability and equity of asset ratio. They concluded that there is significant positive relationship between the bank size and Islamic bank profitability.

They stated that if there is greater capitalization creating low risk, contributes more to banks' profitability. They also concluded that the size of banks impacts the profitability positively. 22Al-Hashimi studied considering net interest margins as a banks' profitability determinant on 10 SSA banks. He proposed that operating efficiencies and credit risk deficiencies make clear the majority of disparity in net interest margins across the region. He found that macroeconomic risk has only partial effects on net interest margin. The relationship between the bank profit and non-interest income ratio is expected to be negative. I have established a model considering the banks' specific factors as the determinants of profitability of banks.

\section{Explanation of Variables:}

- Net interest margin: it is calculated by getting difference between interest income over total assets and interest expenses.

- Bank size: It is book value of equities/total assets.

- Loan growth: (total loans-previous loans)/previous loans

- Insider lending: loans issued to the employee, shareholders and directors.

- Operating expense: operating expense / total expenses

- Non-Performing Loans: the loans declared as non-performing loans/total loans

- Return on Assets: ROA: total return for year/total asset

- Deposit to Asset Ratio: total loans divided by total asset, provide a measure of income source and measures the liquidity of bank assets tied to loans.

\section{Methodology:}

Data:

The data for different variables in our study was obtained from financial statistics analysis (FSA) for the period 2009-2012. For the purpose of the study only chosen commercial banks operating in Pakistan while for special purpose banks were omitted. The sample consisted of bank are operating in Pakistan only. These banks were selected because they had observation for different variables used in our study. The time period for 2009-2012 is ideal because during these years, a Pakistani bank has seen a lot of economic volatility.

\section{Regression Model:}

The following base line regression model will be estimated in our study.

$\operatorname{ROA}_{\mathrm{i}, \mathrm{t}}=\alpha+\beta_{\mathbf{1}}(\mathrm{CAP})_{\mathrm{i}, \mathrm{t}}+\beta_{\mathbf{2}}(\text { Dep growth })_{\mathrm{i}, \mathrm{t}}+\beta_{\mathbf{3}}(\mathrm{LLPR})_{\mathrm{i}, \mathrm{t}}+\beta_{\mathbf{4}}(\text { int } \exp )_{\mathrm{i}, \mathrm{t}}+\beta_{\mathbf{5}}\left(\right.$ (size $_{\mathrm{i}, \mathrm{t}}+\mathrm{E}_{\mathrm{i}, \mathrm{t}}$ Where $\mathrm{CAP}=$ Capital Adequacy calculated as Average total equity divided by total asset, Dep growth=current year divided by previous year minus one, LLPR=Provision against advances divided by total asset, int exp= interest expense divided total deposit, size $=$ natural $\log$ divided by total asset, $\mathrm{E}=$ error term. This ratio shades light on the excess of capital with the bank. Greater the capital adequacy ratio, greater will be the safety of the bank in case of poor economic condition and losses.

\section{Deposit Growth:}

Dep growth $=$ current year divided by previous year minus one

This variable indicates the change in deposit with the bank. Although it is a general perception that a high volume of deposits will increase the profitability of bank. However it's not the sufficient evidence. If these deposits are extended as bad loans, this will negatively impact the profitability of bank. Thus we may not any anticipate any sign at this stage.

Loan Loss Provision (LLPR): deposit.

LLPR=Provision against advances divided by total asset, int exp= interest expense divided total 
This greaterpart will point to that bank is show that bank is convoluted in go forwardimmoral loans and that the banks are losing money on their development. Therefore we expect the negative connotation of this variable with our dependent variable.

\section{Interest Expense:}

Int exp= interest expense divided total deposit

Size:

Size $=$ natural log divided by total asset,

This variable is accepted to have a positive impact on profitability. By having a larger size enable the banks to enjoy the economy of scale further banks with large amount of asset are generally in better position to with stand the impact financial down turn.

Panel Data Regression Model:

We will employee panel data analysis of random, fixed and random effect models.

\section{Common effect Model:}

We will estimate the following common effect model.

$\operatorname{ROA}_{\mathbf{i}, \mathbf{t}}=\alpha+\beta_{\mathbf{1}}(\mathrm{CAP})_{\mathbf{i}, \mathbf{t}}+\beta_{\mathbf{2}}(\text { Dep growth })_{\mathbf{i}, \mathbf{t}}+\beta_{\mathbf{3}}(\mathrm{LLPR})_{\mathbf{i}, \mathbf{t}}+\beta_{\mathbf{4}}(\text { int exp })_{\mathbf{i}, \mathbf{t}}+\beta_{\mathbf{5}}(\operatorname{size})_{\mathbf{i}, \mathbf{t}}+E_{\mathbf{i}, \mathbf{t}}$

The assumption of common effect model is that of homogeneity of cross sectional units. Due to this simplistic assumption, common effect model may not give us robust and generalizable results. Thus we have relay on random and fixed effect model for greater generalizability and robustness.

\section{Fixed Effect Model:}

Fixed effect model is a powerful estimation technique and it allows for heterogeneity of cross sectional units we will estimate the following fixed effect model.

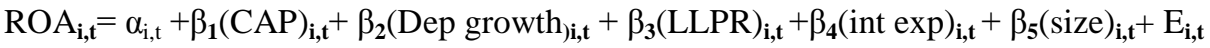

Is the unique intercept for every bank in our study.A side from allying for heterogeneity. It also control for the biases caused by omitted variable.

\section{Random effect Model:}

It is another powerful estimation technique for panel data analysis. It controls for the biases caused by the error term. We will estimate the following random effect model.

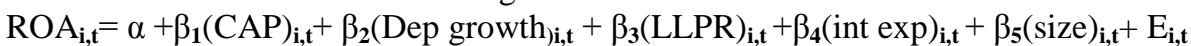

\section{Houseman Test:}

Sometimes due to large observations and smaller time period, fixed and random effects model may give conflicting results. In this scenario we will conduct Housman test under the following hypothesis:

Ho: Random effect results are accepted

H1: Fixed effect results are accepted

A P value of .05 or less will indicate that we will accept the results of fixed effect model and vice versa.

Hetroskadascity Test:

Panel data is prone to the presence of out layers. In order to detect hetroskadascity in our data we will conduct Breuch Pagan-----Cook Wesiberg test for hetroskadascity.

H1: The data is heteroskadastic

H0: The data is nor heteroskadastic

A P value .05 or less will indicate the presence of heteroskadastic.

\section{Descriptive Statistics:}

\section{Results and discussion:}

Table 1 shows the summary statistics of our variables the returned on asset has a mean value of $.1 \%$ while the capital adequacy ratio is almost $13 \%$. The loan loss provision has a mean value of $5.6 \%$ while the deposit growths are have a mean value of $25.6 \%$. Interest expense is at the rate of $8 \%$ while the size has a mean value of $188 \%$. The summary statistics shades a very interesting light on the fact that profit is just $.1 \%$. This clearly shows that increases in deposits have not been proven profitable.

\section{Correlation:}

Table 2 represents the correlation of independent and dependent variables. As it is evident from the correlation matrix, there is no significant correlation among independent variables. This indicates that our analysis is free from multi colinarity. 


\begin{tabular}{r|rrrrrr}
\hline roa & coef. & Std. Err. & $t$ & P> It & {$[95 \%$ Conf. Interval] } \\
\hline cap & .076127 & .0164656 & 4.62 & 0.000 & .0434515 & .1088025 \\
depo & -.1640903 & .0409112 & -4.01 & 0.000 & -.245273 & -.0829033 \\
size & -.0168621 & .0052461 & -3.21 & 0.002 & -.0272727 & -.006451 \\
intexp & -.007477 & .0016069 & 4.65 & 0.000 & .0042881 & .0106658 \\
- cons & -.1093496 & .0723659 & -4.40 & 0.000 & -.4621037 & -.1748883 \\
\end{tabular}

\section{Regression Results:}

We started our analysis by conducting common effect model with standard errors (See Appendix 1) the common effect model revealed are statistically significant coefficient for all independent variables of the study. We then subjected our study to test for hetroskadascity. The results of the test are as follows - hettest

\section{Breusch-Pagan / Cook-Weisberg test for heteroskedasticity Ho: Constant variance Variables: fitted values of roa}

\section{$\operatorname{chi2}(1)=46.37$ \\ Prob $>$ chi2 $=0.0000$}

As outline in the methodology the $\mathrm{P}$ value of the test is less than .05 indicating that our data is heteroskadastic. Thus from this point onwards we will conduct all panel regression models using robust standard errors

\section{Common effect model}

\begin{tabular}{|c|c|c|c|c|c|c|c|}
\hline roa & \multicolumn{3}{|c|}{ Robust } & $P>|t|$ & {$[95 \%$} & Conf. & Interval] \\
\hline cap & .076127 & .0256713 & 2.97 & 0.004 & .0251 & 1831 & .127071 \\
\hline depo & -.0168621 & .0043769 & -3.85 & 0.000 & -.0255 & 5478 & -.0081763 \\
\hline size & .007477 & .001419 & 5.27 & 0.000 & .004 & 1661 & .0102929 \\
\hline intexp & -.318496 & .0810224 & -3.93 & 0.000 & -.4792 & 2824 & -.1577096 \\
\hline -cons & -.1093357 & .0312909 & -3.49 & 0.001 & -.1714 & 1314 & -.04724 \\
\hline
\end{tabular}

\section{Fixed effect model}

\begin{tabular}{r|rrrrrr}
\hline \multirow{2}{*}{ roa } & Coef. & Robust & & & \\
& Std. Err. & $t$ & P>|t| & [95\% Conf. Interval] \\
cap & .1173162 & .0208422 & 5.63 & 0.000 & .0757477 & .1588847 \\
depo & -.1541475 & .0463469 & -3.33 & 0.001 & -.2465835 & -.0617116 \\
size & -.0137808 & .0044363 & -3.11 & 0.003 & -.0226287 & -.004933 \\
intexp & -.037881 & .0076854 & 4.93 & 0.000 & .0225529 & .0532092 \\
_cons & -.6954064 & .153247 & -4.54 & 0.000 & -1.001048 & -.3897649
\end{tabular}

\section{Random effect model}

\begin{tabular}{|c|c|c|c|c|c|c|}
\hline roa & coef. & $\begin{array}{c}\text { Robust } \\
\text { std. Err. }\end{array}$ & z & $\mathrm{P}>|\mathrm{z}|$ & [95\% Conf. & Interval] \\
\hline cap & .07617 & .0250006 & 3.05 & 0.002 & .0271698 & .1251702 \\
\hline $11 \mathrm{p}$ & -.15841 & .0644835 & -2.46 & 0.014 & -.2847954 & -.0320247 \\
\hline depo & -.0130322 & .0036598 & -3.56 & 0.000 & -.0202052 & -.0058592 \\
\hline size & .0082296 & .0017417 & 4.73 & 0.000 & .004816 & .0116432 \\
\hline intexp & -.3052656 & .1033587 & -2.95 & 0.003 & -.507845 & -.1026863 \\
\hline _cons & -.1239051 & .0376897 & -3.29 & 0.001 & -.1977756 & -.0500345 \\
\hline
\end{tabular}

The table shows that results of CE model the table specify a positive significant coefficient for (CAP) and size while (LLPr), deposit growth (depot) and interest expense have significant negative coefficient. In place of this resolution we have also exposed the consequences of fixed and random effect model for the sake of generalizabilityand robustness. The FEmodel indicates a positive significant coefficient for CAP and size while LLP, deposit growth have significant and negative coefficients. Interest expense has a negative significant coefficient. The results of RE model are in association with common effect model. The results of fixed effect and random effect models have dissimilarity. Thus in command to decide among these two models we will meanHouse Man test using the estimates of fixed and random effect model. The results are: 
Determinants of Banks Profitability

\begin{tabular}{|c|c|c|c|c|}
\hline & $\begin{array}{l}\text { (b) } \\
f e\end{array}$ & $\begin{array}{l}\text { (B) } \\
r e\end{array}$ & $\begin{array}{c}(b-B) \\
\text { Difference }\end{array}$ & $\begin{array}{c}\operatorname{sqrt}\left(\text { diag }\left(V_{-} \text {b-V_B }{ }^{-B}\right)\right) \\
\text { S.E. }\end{array}$ \\
\hline cap & .1173162 & .07617 & .0411462 & . \\
\hline $11 \mathrm{p}$ & -.1541475 & -.15841 & .0042625 & . \\
\hline depo & -.0137808 & -.0130322 & -.0007486 & .0025073 \\
\hline size & .037881 & .0082296 & .0296515 & .0074855 \\
\hline intexp & -.3007531 & -.3052656 & .0045125 & .1552735 \\
\hline
\end{tabular}

Value of the $\mathrm{P}$ is less than .05 . This indicates that we will except the results of fixed effect model and ignore the results of random effect model. The fixed effect model assigns a positive coefficient to capital adequacy. The results are in line with the studies the conduct by Bourke (1989). Higher CAP indicates that the banks have significant capital reserves and thus can ward of bankruptcy easily. Further this higher ratio makes banks safer and they can loan the deposits obtained by them more aggressively. Thus banks debt has adequate capital can have more profitability. The loan loss provision wasaccepted to have negative significant impact. This result is alignment with the pass work of Moline and Thornton (1992).

As we indicated in the outset the deposit growth of $25 \%$ a year fail to generate enough profits for the bank. The coefficient has a negative sign because the Pakistani banks were unable to invest this momentous growth in deposits into profitable loan portfolios. This can be attributed to the fact that banks in Pakistan enjoy economy of scales further they have branches all across the country and can extend credit efficiently further, large size banks have lower risk of default as compared to smaller banks also they can experiment with different types of portfolio that further enhance the profitability.

\section{Conclusion:}

The study was conducted by using data obtained from 31 commercial banks operating in Pakistan for the period from 2009-2012. We obtained 140 firm year observation for every variable in our study. The analysis was conducted using panel data estimation technique of common, fixed, random effect model. Our studies have finally revealed a positive coefficient for CAP and size. While Loan loss provision, deposit growth however interest expense prove to be insignificant. These internal determinants of bank profitability indicated that adequate capital and large size helps in banks being profitable. The banks in Pakistan are strictly monitor by the Central bank of the country and also in the past year it has double the capital requirement for starting the banks also our study reveals that banks with a large size such as a bank with lot of branching network are more profitable and can survive in economic down turn. The LLP has a negative significant coefficient which indicates that banks in Pakistan with inefficient loan portfolio will suffer loss. Also we found of that the deposit in growth in Pakistani banks are not utilize efficiently. This results in negative significant coefficient for change in deposits. The government needs to monitor banks, strictly by keeping a system of check and balance so that banks are operated without taking excessive risks. Further it is also suggested that there should be as little influence on banks as possible so that bad loans are at minimum. Thus these steps results in lower loss provision ratio and higher profitability.

\section{References}

[1]. Staikouras, Ch, and G. Wood. "The determinants of bank profitability in Europe."European Applied Business Research Conference, Venice. 2004

[2]. Athanasoglou, Panayiotis P., Sophocles N. Brissimis, and Matthaios D. Delis. "Bank-specific, industry-specific and macroeconomic determinants of bank profitability." Journal of international financial Markets, Institutions and Money18.2 (2008): 121-136.

[3]. Athanasoglou, Panayiotis P., Sophocles N. Brissimis, and Matthaios D. Delis. "Bank-specific, industry-specific and macroeconomic determinants of bank profitability." Journal of international

[4]. financial Markets, Institutions and Money18.2 (2008): 121-136.

[5]. Claessens, Stijn, Aslı Demirgüç-Kunt, and Harry Huizinga. "How does foreign entry affect domestic banking markets?." Journal of Banking \& Finance 25.5 (2001): 891-911.

[6]. Aad, Georges, B. Abbott, J. Abdallah, A. A. Abdelalim, A. Abdesselam, O. Abdinov, B. Abi et al. "The ATLAS simulation infrastructure." The European Physical Journal C 70, no. 3 (2010): 823-874.

[7]. Agarwal, Sunita K., et al. "Menin interacts with the AP1 transcription factor JunD and represses JunD-activated transcription." Cell 96.1 (1999): 143-152.

[8]. Pasiouras, Fotios, and KyriakiKosmidou. "Factors influencing the profitability of domestic and foreign commercial banks in the European Union." Research in International Business and Finance 21, no. 2 (2007): 222-237.

[9]. Treanor, James JS, et al. "Characterization of a multicomponent receptor for GDNF." (1996): 80-83.

[10]. Vong, Sinfia K., et al. "Motivational enhancement therapy in addition to physical therapy improves motivational factors and treatment outcomes in people with low back pain: a randomized controlled trial." Archives of Physical Medicine and Rehabilitation 92.2 (2011): 176-183.

[11]. Tolman, Joel R., et al. "Structural and dynamic analysis of residual dipolar coupling data for proteins." Journal of the American Chemical Society 123.7 (2001): 1416-1424.

[12]. Athanasoglou, P. P., Brissimis, S. N., \& Delis, M. D. (2008). Bank-specific, industry-specific and macroeconomic determinants of bank profitability. Journal of international financial Markets, Institutions and Money, 18(2), 121-136. 